\title{
Homosexuality with Special Refrence Case: Navtej Singh Johar V. Union of India
}

\author{
Dr. Renu1, Pawan² \\ ${ }^{1}$ Associate professor, ${ }^{2}$ Stdedent LL.M \\ 1,2UILS, Chandigarh University, Mohali, Punjab, India
}

\begin{abstract}
How to cite this paper: Dr. Renu | Pawan "Homosexuality with Special Refrence Case: Navtej Singh Johar V. Union of India" Published in International Journal of Trend in Scientific Research and Development (ijtsrd), ISSN: 24566470, Volume-3 | Issue-4, June 2019, pp.16-19, URL: https://www.ijtsrd.c om/papers/ijtsrd23 555.pdf

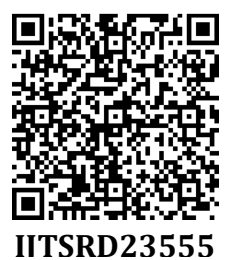

Copyright (C) 2019 by author(s) and International Journal of Trend in Scientific Research and Development Journal. This is an Open Access article distributed under the terms of the Creative Commons

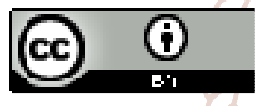
Attribution License (CC BY 4.0) (http://creativecommons.org/licenses/ by/4.0)
\end{abstract}

\section{INTRODUCTION}

Homosexuality refers to sexual interaction between individual of same gender. Homosexuality has been broadly insulted as freak or corrupt conduct in many societies, frames of mind originating from religious and philosophical thoughts regarding what practices are accord with nature and normal law. Then again, many cultures from the beginning of time have explicit jobs for sensual love and sexual articulation between same sex people. ${ }^{1}$

Today attitude towards homosexuality are charging from hostility to tolerance as efforts are made to combat homophobic prejudice, to end discrimination and to ensure the civil right of all people irrespective of their sexual orientation.

In this era of modernity, Indian culture has also become modern and considered homosexuality as legal. On September 6, 2018 Hon'ble Supreme Court declared section377 of IPC, 1860 unconstitutional and provide homosexuality a status of legality. It means homosexuality is no more offence India. Homosexuality over the years used by different terms. Presently it is known as LGBTQ. LGBTQ

\footnotetext{
${ }^{1}$ SuparnaBhaskaran,"Made in India:

Decolonizations,QueerSexualities,Trans/National”,Palgrav e Macmillan,US,2004;25.
}

stand for Lesbian, Gay, Bisexual, Transgender ${ }^{2}$ and Queer and along with heterosexuality they describe people's sexual orientation or gender identity.

Lesbian: -A lesbian refers to woman who is romantically, sexually and emotionally attracted to a woman.

Gay: -A gay man is one who is romantically, sexually and emotionally attracted to man.

Bisexual: - a bisexual person is someone who is romantically, sexually and emotionally attracted to people of both sexes.

Transgender: - it is an umbrella term used to describe people whose gender identity and gender expression, differs from that usually associated with their birth sex. ${ }^{3}$

\footnotetext{
2Pobal(organization) Staff,"More Than a Phase:A Resource Guide for the Inclusion of Young Lesbian,Gay,Bisexual and Transgender Learners", Area Development Management Limited,2006;9.

3Jens M. Scherpe, "The Legal Status of Transsexual and Transgender Persons",Intersentia press,Cambridge(United Kingdom), 2015; 45.
} 
Queer: - A political explanation, just as a sexual introduction, which advocates breaking binary reasoning and seeing both sexual introduction and sex way of life as possibly liquid. The term is a basic mark to clarify a mind-boggling set of sexual practices and wants. For instance, an individual who is pulled in to numerous sexes may recognize as eccentric. Numerous more established LGBT individuals feel the word has been derisively utilized against them for a really long time and are hesitant to grasp it. "Queer" can be used as an umbrella term to insinuate all LGBTQI people.

\section{LEGALIZATION OF LGBTQ COMMUNITY: - (LEGAL INCLUSION)}

The Williams Institute's second report "Examining Relationship between social acceptance of LGBTQ people and legal inclusion of sexual minorities" found a strong relationship between legal inclusiveness \& acceptance of $L G B T Q^{4}$

\section{International legal inclusiveness: -}

There have been many positive developments in favor of LGBTQ community on international front.

In May 2015: - Ireland legalized same-sex marriage. The country which had decriminalized homosexuality in 1993 became first country to allow same sex marriage.

In June, 2015 US Supreme court ruled that same sex marriage was legal.

France, UK, Canada, US, Australia \& Brazil have decriminalized homosexuality.

Indian Supreme court recently passed a judgment declaring Section-377 of Indian Penal Code, 1860 unconstitutional \& conferring legal status on LGBT community. ${ }^{5}$

Section 377 IPC, 1860 Till 2018, in India LGBT community were illegal and punishable under Section 377 of IPC, 1860 (the national criminal law of country).

Section 377 provides for "Unnatural offences -Whoever voluntarily has carnal intercourse against the order of nature with any man, woman or animal, shall be punished with 1 [imprisonment for life], or with imprisonment of either description for a term which may extend to ten years, and shall also be liable to fine.

Explanation-Penetration is sufficient to constitute the carnal intercourse necessary to the offence described in this section."6

\section{HISTORY}

Homosexual people have existed always. The origin and development of sexuality is hand to be traced with complete accuracy, as it was a subdued affair for all ages. But the various anthropological, archaeological and literary evidences have confirmed existence of homosexuality in all

\footnotetext{
${ }^{4}$ Adrian Thatcher, "The Oxford Handbook of Theology, Sexuality, and Gender", Oxford University Press,United Kingdom,2014;130.

5 Available at: https:iasscore.in/national-issues/-shouldhomosexuality-377-of-ipc-be-decriminalized-(last accessed on October 1,2018 at 12:48 pm).

${ }^{6}$ Indian Penal Code,1860(45 of 1860).
}

primitive societies of world. Homosexuality has been an issue since the history can recall: ancient Greece, Rome Egypt, china all civilization has peculiar belief on its identity. ${ }^{7}$

Homosexuality exist from the time of existence of human being.It was also prevalent in many early religions.

$>$ The Hindu God Samba reduced mortal man.

$>$ Zeus had relation with Ganymede and

$>$ Homosexuality was considered only a mind transgression in Buddhism.

$>$ Male homosexuality common among the Aztecs. ${ }^{8}$

In Greece, relationship between two men were treated as the highest \&most appreciated kind of love from ancient time

In $\boldsymbol{U S}$, Homosexual relation has deep history but considerably found footsteps in $20^{\text {th }}$ century during first half when people migrated to large cities to find work \& lived away from their families.

In India,in Indian condition it is trusted that the LGBTQ people group is current idea and started in twentieth century however the fact of the matter is extraordinary. Indian stories like Ramayana, Mahabharata and even sanctuaries of Khajuraho give enough peep into old occasions of India to build up that homosexuality was by and by.

In Temple of Khajuraho there are Image of women erotically embracing other women \& men displaying their genital to each other. In the Valmiki Ramayana, Lord Rama's devotee and companion Hanuman is said to have seen Rakshasa women kissing \& embracing other women. $19^{\text {th }}$ chapter of Kamasutra of Vatsyayana composed in around $4^{\text {th }}$ century BC, talks about oral sexual acts(Auparistaka). Arthashashtra of Kautliya - a treatise on politics also mentioned homosexuality. ${ }^{9}$

\section{DEVELOPMENT OF LGBT COMMUNITY}

LGBT initially considered to be sin behaviors. Societal frame of mind toward same - sex relationship has differed over the time and spot from anticipating that all guys should take part in same-sex connections to easygoing mix through acknowledgment to considering practice to be minor sin. Average level of acceptance for LGBTQ people and their rights have increased globally since 1980, but to new research from William Institute at UCLA school of Law. The examination, which was separated into trio of report, utilized information accumulated from worldwide and territorial popular feeling studies from 141 nations between 1980 and 2014.The principle Report utilizes the William Institute's New "Worldwide Acceptance Index" to gauge and analyze LGBTQ. 
First Report: - "Polarized Progressed"10

80 Countries experienced increased (57\%)

46 Countries experienced decline (33\%)

15 Countries experienced no change $(11 \%)$

\section{CASE \\ NAVTEJ SINGH JOHAR V. UNION OF INDIA ${ }^{11}$}

Navtej Singh Johar\&Ors. v. Union of India. Secretary Ministry of Law and Justice is a milestone choice of the Supreme Court of India in 2018 that decriminalized all consensual sex among adults in private, including gay sex. The court was solicited to decide the legality from Section 377 of the Indian Penal Code, a frontier period law which, in addition to other things, condemned gay goes about as an "unnatural offense". While the statute criminalizes all anal sex and oral sex, including between opposite-sex couples, it largely affected same-sex relationships. On 6 September 2018, the court unanimously declared the law unconstitutional "in so far as it criminalizes consensual sexual conduct between adults of the same sex". The decision was hailed as a milestone choice for LGBT rights in India, with campaigners holding up outside the court cheering after the decision was articulated. Parts of Section 377 identifying with sex with minors, nonconsensual sexual acts such as rape, and bestiality remain in force. ${ }^{12}$

On 27 April 2016, five people filed a new writ petition in the Supreme Court challenging the constitutionality of Section 377 of the Indian Penal Code. The petitioners claimed that the issues which they raised in their petition were varied and diverse from those raised in the pending curative petition in the 2013 Koushal v. Naz case, in which the Supreme Court had upheld the constitutionality of Section 377.The Naz had been before alluded to a five-judge seat so as to choose whether the curative petition could be accepted for consideration. The solicitors were dancer Navtej Singh Johar, journalist Sunil Mehra, chef Ritu Dalmia, hoteliers Aman Nath and Keshav Suri, and businessperson Ayesha Kapur. This case was the principal example wherein the applicants contended that they had all been legitimately distressed in view of Section 377, charging it to be an immediate infringement of basic rights. ${ }^{13}$

The petition was 1st placed before Justice S. A. Bobde and Justice A. K. Bhushan on 29 June 2016. An order was passed to post the matter before the Chief Justice of India, Justice Dipak Misra for appropriate orders since a curative petition was already pending before the constitution bench. ${ }^{14}$ On 8 January 2018, the case (Navtej Singh Johar and others v. Union of India) was listed to be heard by the Chief Justice's seat, which passed a request expressing that the case would be heard by a constitution bench.The matter was gotten

${ }^{10}$ Available at:https://www.nbcnews.com(Last accessed on May 03,2018).

${ }^{11}$ AIR 2016 SC 76.

12 "Historic India ruling legalises gay sex". BBC News. 6 September 2018 (Last visited on 6 September 2018).

13 "Gay sex decriminalised: History owes apology to LGBT community and kin, says Supreme Court". The Indian Express. Express Web Desk. New Delhi: Indian Express Group. September 6, 2018. OCLC 70274541 (Last visited on October 26, 2018).

14 "Supreme Court Order - NavtejJohar vs Union of India 29 June 2016" (PDF). Archived from the original (PDF) on 15 November 2018. notification from 17 January 2018 by a five-judge constitution seat of the Supreme Court. On 10 July 2018, the SC initiated becoming aware of the supplications testing the legality of segment 377 . The seat finished its hearing on 17 July and saved its decision, requesting the two sides to submit composed entries for their cases by 20 July.

On 6 September 2018, the court conveyed its consistent decision, proclaiming bits of the law identifying with consensual sexual acts between adults illegal. This decision upsets the 2013 managing in Suresh Kumar Koushal v. Naz Foundation in which the court maintained the law. In any case, different bits of Section 377 identifying with sex with minors, non-consensual sexual acts, and savagery stay in power. The court found that the criminalization of sexual acts between consenting adults damaged the privilege to equity ensured by the Constitution of India. While perusing the judgment, Chief Justice Misra articulated that the court found "criminalizing carnal intercourse" to be "irrational, arbitrary and manifestly unconstitutional". The court decided that LGBT individuals in India are qualified for every single established right, including the freedoms ensured by the Constitution of India. It held that "the choice of whom to associate, the ability to find fulfillment in sexual affections and the benefit not to be presented to biased direct are normal for the consecrated security of sexual presentation". The judgment likewise made note that LGBT people group is qualified for equivalent citizenship and insurance under law, without discrimination. ${ }^{15}$

\section{CONCLUSION}

Societies all over the world are permanently changing. The life style of many persons differs considerable from that of previous generation. In many countries this also has consequences in respect of family law. Old traditional rules are confronted with new facts and circumstances and are therefore under pressure to be modified by the court or legislators. The most important task is to educate the public andraise public awareness about sexual minorities. They deserve one of the most important right i.e Right to Equality.In the case of, Navtej Singh Johar V. Union of India Hon'ble Supreme Court held that section 377 as Unconstitutional. The decision was given by Five Judges Bench. The Supreme Court ruled consensual intercourse among adult homosexuals or heterosexuals in private space does not harm public decency or morality. In a landmark verdict, the judges, held that Section 377 of the Indian Penal Code had become an "odious weapon" to harass the LGBT community which was made "societal pariah" by subjecting them to discrimination and unequal treatment. The CJI held that Section 377 in its present form violated Article 19(1)(a) that deals with freedom of speech and expression.

\section{REFRENCES}

[1] BhaskaranSuparna, "Made in India: Decolonizations, QueerSexualities,Trans/National",Palgrave Macmillan, US,2004.

[2] Jens M. Scherpe, "The Legal Status of Transsexual and Transgender

Persons",Intersentiapress,Cambridge(United Kingdom), 2015.

\footnotetext{
${ }^{15}$ Navtej Singh Johar\&Ors. v. Union of India thr. Secretary Ministry of Law and Justice, W. P. (Crl.) No. 76 of 2016 (Supreme Court of India).
} 
International Journal of Trend in Scientific Research and Development (IJTSRD) @ www.ijtsrd.com eISSN: 2456-6470

[3] Thatcher Adrian, "The Oxford Handbook of Theology, Sexuality, and Gender", Oxford University Press,United Kingdom,2014.

[4] VanitaRuth andKidwai Saleem, "Same-Sex Love in India: A Literary History”,Palgrave Macmillan, US,2000.

[5] Pobal(organization) Staff, "More Than a Phase:A Resource Guide for the Inclusion of Young Lesbian,Gay,Bisexual and Transgender Learners", Area Development Management Limited,2006.

[6] "Historic India ruling legalises gay sex". BBC News. 6 September 2018.

[7] "Gay sex decriminalized: History owes apology to LGBT community and kin, says Supreme Court". The Indian Express. Express Web Desk. New Delhi: Indian Express Group. September 6, 2018. OCLC 70274541.
[8] "Supreme Court Order - NavtejJohar vs Union of India 29 June 2016" (PDF). Archived from the original (PDF) on 15 November 2018.

[9] Navtej Singh Johar\&Ors. v. Union of India thr. Secretary Ministry of Law and Justice, W. P. (Crl.) No. 76 of 2016 (Supreme Court of India).

[10] Available at:https: // theweek. com/ articles amp/ 528979 / origins-homosexuality.

[11] Available at:https://www.nbcnews.com.

[12] Available at: https:iasscore.in/national-issues/-shouldhomosexuality-377-of-ipc-be-decriminalized.

[13] Indian Penal Code, 1860(45 of 1860).

[14] AIR 2016 SC 76. 